\title{
Extraction of carrageenan from Eucheuma spinosum using ohmic heating: optimization of extraction conditions using response surface methodology
}

\author{
Andi HASIZAH ${ }^{1}$, Meta MAHENDRADATTA ${ }^{1}$, Amran LAGA ${ }^{1}$, Metusalach METUSALACH ${ }^{2}$, \\ Salengke SALENGKE ${ }^{3 *}$ (D)
}

\begin{abstract}
Seaweed is an important global commodity since it is the source of many important products such as carrageenans, agar, alginates, and bioactive compounds. Seaweed processing is an energy intensive process since it involves heating large volumes of seaweeds in alkali solutions at high temperatures for up to six hours. To increase energy efficiency, an ohmic based processing system has been developed but has not been tested thoroughly. Therefore, the objective of this study was to identify optimum processing conditions for extraction of carrageenan from Eucheuma spinosum using ohmic heating technology. The experiment was conducted using Central Composite Design with four variables, i.e. extraction temperature, extraction duration, $\mathrm{KOH}$ concentration, and solution to seaweed ratio. Following the extraction process, carrageenan was recovered through precipitation using 90\% isoprophyl alcohol solution. Results of experiments indicate that extraction yields varied from 29.6-62.4\% dry basis with viscosity and gel strength varied from $259-290 \mathrm{mPa} . \mathrm{s}$ and $42.54-70.41 \mathrm{~g} / \mathrm{cm}^{2}$ respectively. Statistical analysis indicated that extraction yield can be adequately modeled using the four variables and optimum extraction yield (61.59\%), gel strength $\left(53.48 \mathrm{~g} / \mathrm{cm}^{2}\right)$, and viscosity $(284.51 \mathrm{mPa} . \mathrm{s})$ were achieved at $95{ }^{\circ} \mathrm{C}$ extraction temperature, 240 minutes of extraction time, $0.4 \mathrm{M} \mathrm{KOH}$ concentration, and 45:1 solution to seaweed ratio.
\end{abstract}

Keywords: ohmic technology; carrageenan extraction; optimization; Eucheuma spinosum.

Practical Application: Carrageenan extraction based on ohmic heating has been developed and tested. This technology is very promising since it can provide extraction yield and carrageenan quality comparable to conventional heating technology but with potentially faster extraction process due to the fast and uniform heating and more energy efficient since heat is generated internally within the extraction chamber.

\section{Introduction}

Seaweed is an important global commodity since it is the source of many important commercial products such as carrageenans, agar, and alginates. In addition, many species of seaweeds have been identified as the source of bioactive compounds and coloring agents. Processing of seaweeds into valuable products is an energy intensive process. Current technologies in seaweed processing generally use double jacketed tanks supplied with steam for heating of processed seaweeds in alkali solutions. In those technologies, processing systems are complicated since they require dedicated steam generators and steam delivery systems. Therefore, simpler and more energy efficient processing technologies are needed and a recent publication by Hasizah et al. (2018) has reported a novel technology for extraction of carrageenan using ohmic heating.

Ohmic heating technology was originally developed for pasteurization and sterilization purposes. Records indicate that the use of ohmic heating in food processing was initially developed for pasteurization of milk in the 1930s (Getchel, 1935; Moses, 1938). However, this technology disappeared thereafter due to electricity cost and technical difficulties (Alwis \& Fryer, 1990).
Since the development of commercial ohmic heating units for food sterilization by APV Baker (England) in 1980's, researchers from universities and research institutions have conducted numerous studies on ohmic heating of food products. Studies on application of ohmic heating has been carried out on fruits and vegetables (Mizrahi, 1996; Lima \& Sastry, 1999; Wang \& Sastry, 2002; Salengke \& Sastry, 2005, 2007a; Sarang et al., 2008), juices and purees (Sastry \& Palaniappan, 1991; Castro et al., 2003, 2004; Icier \& Ilicali, 2005; Mercali et al., 2013; Darvishi et al., 2013; Achir et al., 2016; Abedelmaksoud et al., 2018), liquid eggs (Icier \& Bozkurt, 2011; Darvishi et al., 2012; Kasler \& Sastry, 2019), meat and fish (Shirsat et al., 2004; Halleux et al., 2005; Sarang et al., 2008; Zell et al., 2009; Bozkurt \& Icier, 2010; Fattahi \& Zamindar, 2020), and dairy based products (Bansal \& Chen, 2006; Pires et al., 2020; Kuriya et al., 2020; Rocha et al., 2020a, b).

One of the most important findings reported in literature regarding ohmic heating is that it can deliver rapid, uniform, and efficient heating for liquid and solid foods as well as for foods containing mixtures of liquid and solid particulates (Bansal \& Chen, 2006; Salengke \& Sastry, 2007b, c; Pires et al., 2020). In addition, several researchers have reported that 
ohmically processed products have superior quality compared to those processed using conventional heating (Pires et al., 2020; Rocha et al., 2020a, b) and may have positive effects on health as found in experiments on rats (Rocha et al., 2020b). In addition, Rocha et al. (2020a) reported that pasteurization of milk using ohmic heating at low electric field strength $(<8 \mathrm{~V} / \mathrm{cm})$ can contribute to the formation of bioactive compounds in cheeses produced from the milk but negatively affected fatty acid profile of the cheeses. The aforementioned characteristics of ohmic heating are desirable in seaweeds processing since the volumes of materials (extracting solution and seaweed) processed are generally large. Under this condition, high and uniform heating rates are required to achieve an efficient extraction process.

The rate and the uniformity of ohmic heating are largely dependent on the electrical conductivity of the processed materials. For biological materials and electrolytes, electrical conductivity depends on temperature and the concentration and the species of ions contained in the processed materials. Several researchers (Sastry \& Palaniappan, 1991; Castro et al., 2003; Icier \& Ilicali, 2005; Bozkurt \& Icier, 2010; Darvishi et al., 2013) have reported that electrical conductivity of food materials increased linearly with temperature. Similar trends were reported for electrical conductivity of dilute $\mathrm{KOH}$ solution during ohmic heating (Hasizah et al., 2018).

Processing of seaweeds for carrageenan, agar-agar, and alginate productions is commonly done under alkaline condition to increase gel strength and the most used alkali is potassium hydroxide $(\mathrm{KOH})$. This is due to the fact that potassium ions are effective in modifying the gel strength of the hydrocolloids contained in seaweeds. The concentrations of $\mathrm{KOH}$ that have been used by researchers in seaweed processing studies ranged from 0.05-4M (Ciancia et al., 1993; Chandramishra et al., 2006; Tuvikene et al., 2006).

Potassium hydroxide solutions have high electrical conductivities since $\mathrm{KOH}$ can completely dissociate into ions in aqueous solution and form a strong electrolyte. Measurements under ohmic heating conditions have shown that the electrical conductivity of dilute $\mathrm{KOH}$ solutions at room temperature ranged from $8.15 \mathrm{~S} / \mathrm{m}$ to $22.78 \mathrm{~S} / \mathrm{cm}$ at concentration range of 0.3 to $0.9 \mathrm{M}$ (Hasizah et al., 2018). Due to the high electrical conductivity of $\mathrm{KOH}$ at this concentration range, ohmic heating rates are high such that rapid heating of solution can be achieved. Therefore, the use of ohmic heating technology in seaweed processing is promising.

Carrageenans in seaweeds are contained in the cell walls and at intra cell matrices. To effectively extract the carrageenans from seaweeds, the cell walls and cell matrices must be disrupted to allow the carrageenans to leach out of the cell matrices. This can be achieved by heating the seaweeds at temperatures above the melting temperature of the carrageenan. Therefore, one of the important factors affecting extraction yield is extraction temperature. Other factors that may also affect yield are extraction duration, alkali concentration, and solution to seaweed ratio. In order to obtain maximum extraction yield and optimum properties of carrageenan produced, extraction must be carried out under optimum conditions.
Studies on optimization of process condition for carrageenan extraction are still scarce and only three studies have been found in literatures (Webber et al., 2012; Bono et al., 2014; Anisuzzama et al., 2014). These researchers studied extraction of carrageenan from Kappaphycus alvarezii and the parameters used were extraction temperature and duration (Webber et al., 2012), temperature, duration, and $\mathrm{KOH}$ concentration (Bono et al., 2014), and $\mathrm{KOH}$ concentration and cooking duration (Anisuzzama et al., 2014). The overall results reported from these studies indicate that the above experimental parameters can affect extraction yield, viscosity and gel strength of carrageenan produced.

It is important to note that all of the aforementioned studies were done using micro-scale experiments with conventional heating method. Currently, study on extraction of carrageenan using alternative heating methods has been scarce. Only two such studies have been reported; one study used microwave heating (Uy et al., 2005) and the other used ohmic heating (Hasizah et al., 2018). The results reported in this last study indicate that extraction of carrageenan from Eucheuma spinosum using pilot-scale ohmic heating resulted in relatively higher yield than the results reported by several researchers using conventional heating. However, further studies need to be done to identify optimum conditions for carrageenan extraction using larger scale ohmic heating chambers.

The use of ohmic heating in carrageenan extraction can potentially increase extraction yield since ohmic heating has been reported to cause electroporation in biomaterials as indicated by the increase in juice yields (Lima \& Sastry, 1999; Wang \& Sastry, 2002), plant tissue damage (Lebovka et al., 2005), and enhanced diffusion (Schreier et al., 1993; Kulshrestha \& Sastry, 2003). Therefore, the objective of this study was to obtain optimum conditions for extraction of refined carrageenan from Eucheuma spinosum using a pilot scale static ohmic heating system.

\section{Materials and methods}

\subsection{Material}

Experiments on extraction of carrageenan from Eucheuma spinosum were carried out using a pilot scale static ohmic heating system. The seaweed was harvested at 45 days after transplantation and sun dried to about 35\% moisture content. Prior to experiment, the seaweed was thoroughly cleaned by brushing off salt residues and sands from the surface of the seaweed and washing using tap water. The clean seaweed was then sun dried to about $10 \%$ moisture content and weighed to predetermined weights. The samples were placed in plastic bags and stored in airtight containers at room temperature.

\subsection{Equipment setup}

The ohmic heating chamber used in this study was made of a PVC (polyvinyl chloride) pipe (internal diameter $10.25 \mathrm{~cm}$ and length of $100 \mathrm{~cm}$ ) equipped with stainless steel electrodes at both ends of the chamber. Electric energy was supplied to the ohmic heating chamber using a custom built 75-Amps power supply system equipped with a thermo-controller which control extraction temperature and the supply of electric current to the electrodes. A data logging system was used to record electric 
current consumption, applied voltage, and temperature of solution inside the heating chamber during extraction.

\subsection{Extraction experiment}

Seaweed samples were soaked in tap water for 30 minutes before each experiment and extraction was carried out using $\mathrm{KOH}$ solution. After extraction, the solution containing the extracted carrageenan was separated from solid residues by filtration. The carrageenan contained in the filtrate was precipitated using $90 \%$ isoprophyl alcohol (IPA) with IPA to filtrate ratio of $2: 1(\mathrm{v} / \mathrm{v})$. The precipitated carrageenan was separated from the solution by filtration, rinsed with IPA solution and sun dried to about 12 percent moisture content.

The experiment was based on Central Composite Design (CCD) with four factors, namely extraction temperature $\left(X_{1}\right)$, extraction duration $\left(X_{2}\right), \mathrm{KOH}$ concentration $\left(X_{3}\right)$, and $\mathrm{KOH}$ solution to seaweed ratio $\left(X_{4}\right)$. Five levels of each factor (coded $-\alpha,-1,0,+1$, and $+\alpha$ ) were chosen for the experiment to investigate the main effects of each factor and their interaction. The experimental range and levels of each factor used in this study are given in Table 1 and all experiments were repeated twice. Responses measured were extraction yield, gel strength, and viscosity. Extraction yields (dry basis) were calculated as the ratio between the dry weight of carrageenan obtained and the dry weight of the seaweed processed. The gel strength of $1.5 \%$ carrageenan gel was measured at room temperature using a texture analyser (Stable Micro Systems, Surrey, UK) equipped with Bloom test apparatus. Viscosity of $1.5 \%$ carrageenan solution was measured at $75^{\circ} \mathrm{C}$ using a viscometer (Brookfield Engineering, Middleboro, Massachusetts, US). The data obtained were analysed using Design Expert Version 10 (Stat-Easy Inc., Minneapolis, MN) to determine the best combination of the experimental factors for optimum yield, gel strength, and viscosity, and to generate surface plots. The mathematical models generated by the software were validated experimentally at the optimum conditions.

\section{Results and discussions}

The experimental design generated by CCD consisted of 31 experimental runs which consisted of 16 factorial points, 8 star points, and 7 center points. Results of measurements of the three responses (average of two measurements) for the 31 experimental runs are given in Table 2 and results of analysis of variance for response surface model for extraction yields, gel strength, and viscosity are shown in Table 3. It is important to note that only the $F$ and $p$ values are shown in Table 3 due to space consideration.

\subsection{Extraction yield}

The data shown in Table 2 indicate that extraction yields varied from $29.6 \%$ to $62.39 \%$ with an average of $48.84 \%$. The yields obtained were in the range reported previously by other researchers (Dawes, 1977; Fostier et al., 1992; Istini et al., 1994; Buriyo et al., 2001; Vairappan et al., 2003; Freile-Pelegrin et al., 2006; Wakibia et al., 2006; Freile-Pelegrin \& Robledo, 2007). The variation of extraction yields obtained in this study showed that the extraction yield was affected by the four experimental variables used in this study. It is also worthy of note that based on the extraction yields, ohmic heating technology for carrageenan extraction can become a viable alternative.

Results of statistical analysis (not shown due to space consideration) from Design Expert Software for the yield data indicate that extraction yield can be best predicted using a quadratic model with an F-value of 4.84 and p-value $=0.0094(<<0.05)$. The result of the lack of fit test indicates that the lack of fit for the quadratic model is insignificant $(p=0.6848)$ which also indicates that the quadratic model can provide adequate prediction for extraction yields.

Results of analysis of variance for response surface model for extraction yields (Table 3 ) indicates that the significant factors $(p<0.05)$ in the quadratic model are extraction temperature, extraction duration, and $\mathrm{KOH}$ to seaweed ratio. The effect of $\mathrm{KOH}$ concentration on extraction yield was insignificant $(p>0.05)$. The $F$ value $(13.63)$ and the $p$ value $(<0.0001)$ of the model suggests that all of the factors in the model provide significant contribution to the prediction of extraction yield. The quadratic models for the prediction of extraction yield are presented in Equation 1 (for coded factors) and Equation 2 (for actual factors).

$$
\begin{aligned}
Y= & 49.47+5.03 X_{1}+4.15 X_{2}+4.20 X_{4}-2.40 X_{1} X_{4}+1.78 X_{1}^{2}-2.60 X_{2}^{2} \\
Y= & 335.674-10.165 T+0.329 t+4.7318 R-0.0479 T R+ \\
& 0.0714 T^{2}-0.000722 t^{2}
\end{aligned}
$$

The regression equations (Equations 1 and 2) show that extraction yield is a quadratic function of extraction temperature and duration and a linear function of the ratio between the volume of $\mathrm{KOH}$ solution and the weight of seaweed (simply referred to as the ratio). It can also be seen from the equations that the interaction between extraction temperature and the ratio also significantly affected extraction yield. On the other hand, $\mathrm{KOH}$ concentration in the range of 0.4 to $0.8 \mathrm{M}$ as used in this study did not significantly affect on extraction yield. The corresponding response surface plots for extraction yields

\begin{tabular}{|c|c|c|c|c|c|c|}
\hline Experimental Variables & Code & $-\alpha$ & -1 & 0 & 1 & $+\alpha$ \\
\hline Temperature, $\mathrm{C}$ & $\mathrm{X}_{1}$ & 80 & 85 & 90 & 95 & 100 \\
\hline Extraction duration, min & $\mathrm{X}_{2}$ & 60 & 120 & 180 & 240 & 300 \\
\hline $\mathrm{KOH}$ concentration, $\mathrm{M}$ & $\mathrm{X}_{3}$ & 0.2 & 0.4 & 0.6 & 0.8 & 1.0 \\
\hline $\mathrm{KOH}$ to Seaweed ratio, v/w & $\mathrm{X}_{4}$ & $15: 1$ & $25: 1$ & $35: 1$ & $45: 1$ & $55: 1$ \\
\hline
\end{tabular}
based on Equation 2 are given in Figure 1.

Table 1. Experimental range and levels of the experimental variables used in the CCD design. 
Hasizah et al.

Table 2. CCD experimental design with coded and actual levels and measured responses.

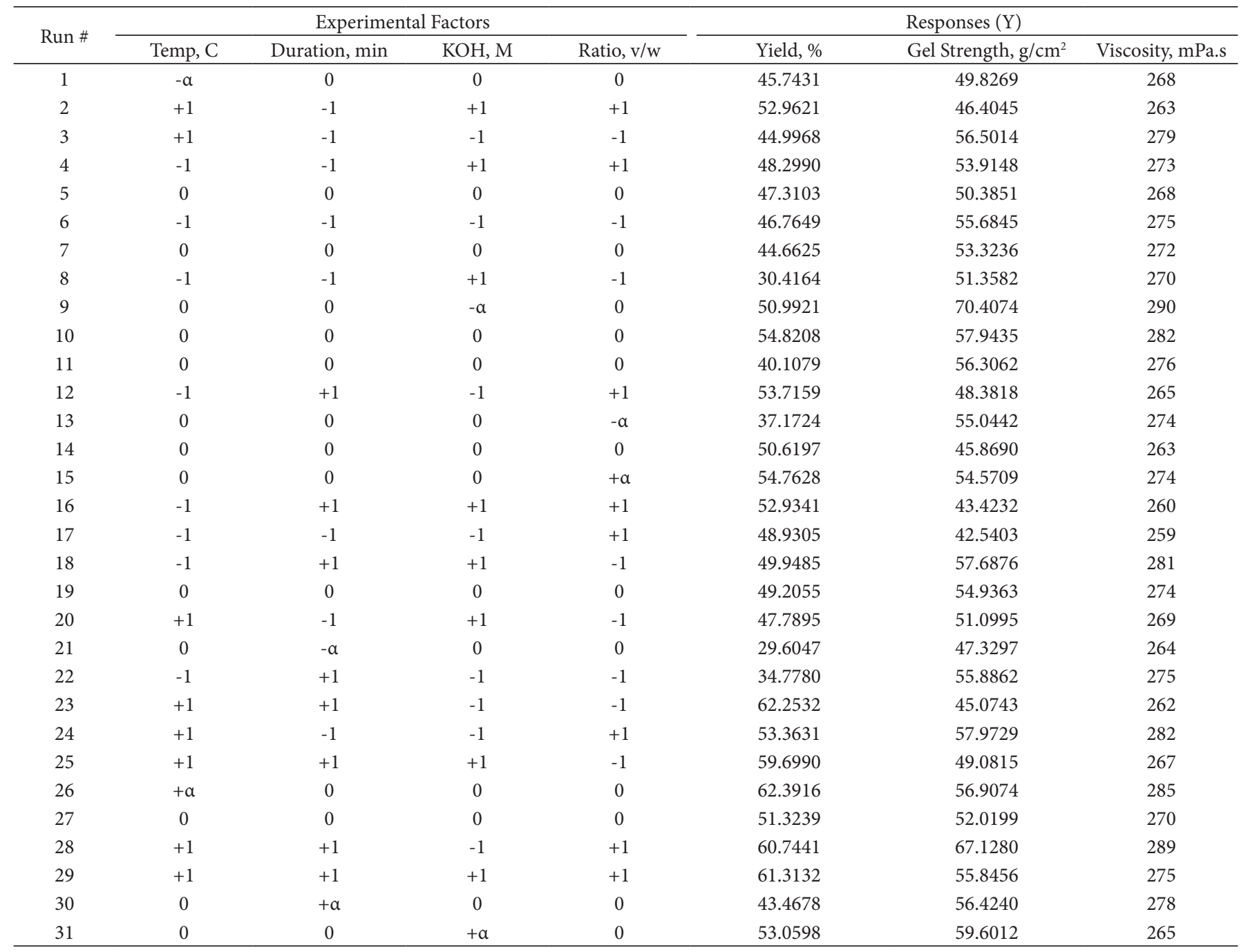

The responses (Y) were the mean values of two replicates.

Table 3. Summary of results of analysis of variance for response surface reduced quadratic models for extraction yield, gel strength and viscosity (only $F$ and $p$ values are presented).

\begin{tabular}{|c|c|c|c|c|c|c|}
\hline \multirow{2}{*}{ Source } & \multicolumn{2}{|c|}{ Extraction yield } & \multicolumn{2}{|c|}{ Gel Strength } & \multicolumn{2}{|c|}{ Viscosity } \\
\hline & F Value & Prob $>F$ & F Value & Prob $>F$ & F Value & Prob $>F$ \\
\hline Model & 13.63 & $<0.0001$ & 4.15 & 0.0070 & 4.27 & 0.0061 \\
\hline Temperature, $T$ & 34.54 & $<0.0001$ & 1.97 & 0.1729 & 3.70 & 0.0660 \\
\hline Duration, $t$ & 23.54 & $<0.0001$ & - & - & - & - \\
\hline $\mathrm{KOH}, \mathrm{C}$ & 0.34 & 0.5663 & 2.93 & 0.0993 & 5.85 & 0.0232 \\
\hline Ratio, $R$ & 24.12 & $<0.0001$ & 0.099 & 0.7558 & 0.14 & 0.7129 \\
\hline$T^{2}$ & 6.07 & 0.0220 & - & - & - & - \\
\hline$t^{2}$ & 10.00 & 0.0045 & - & - & - & - \\
\hline$C^{2}$ & 3.27 & 0.0841 & 7.38 & 0.0118 & - & - \\
\hline Lack of Fit & 0.67 & 0.7604 & 1.70 & 0.2634 & 1.23 & 0.4258 \\
\hline
\end{tabular}

The predicted extraction yields shown in Figure 1a were calculated at temperature range of $85-95{ }^{\circ} \mathrm{C}$ and extraction duration of 120-240 minutes while $\mathrm{KOH}$ concentration and solution to seaweed ratio were at central points of $0.6 \mathrm{M}$ and
35:1 respectively. The response surface curve shown in Figure $1 \mathrm{~b}$ was generated using the predicted extraction yields at $85-95^{\circ} \mathrm{C}$ temperature range and ratio of solution to seaweed was in the range of 25:1 to 45:1 while $\mathrm{KOH}$ concentration and extraction 

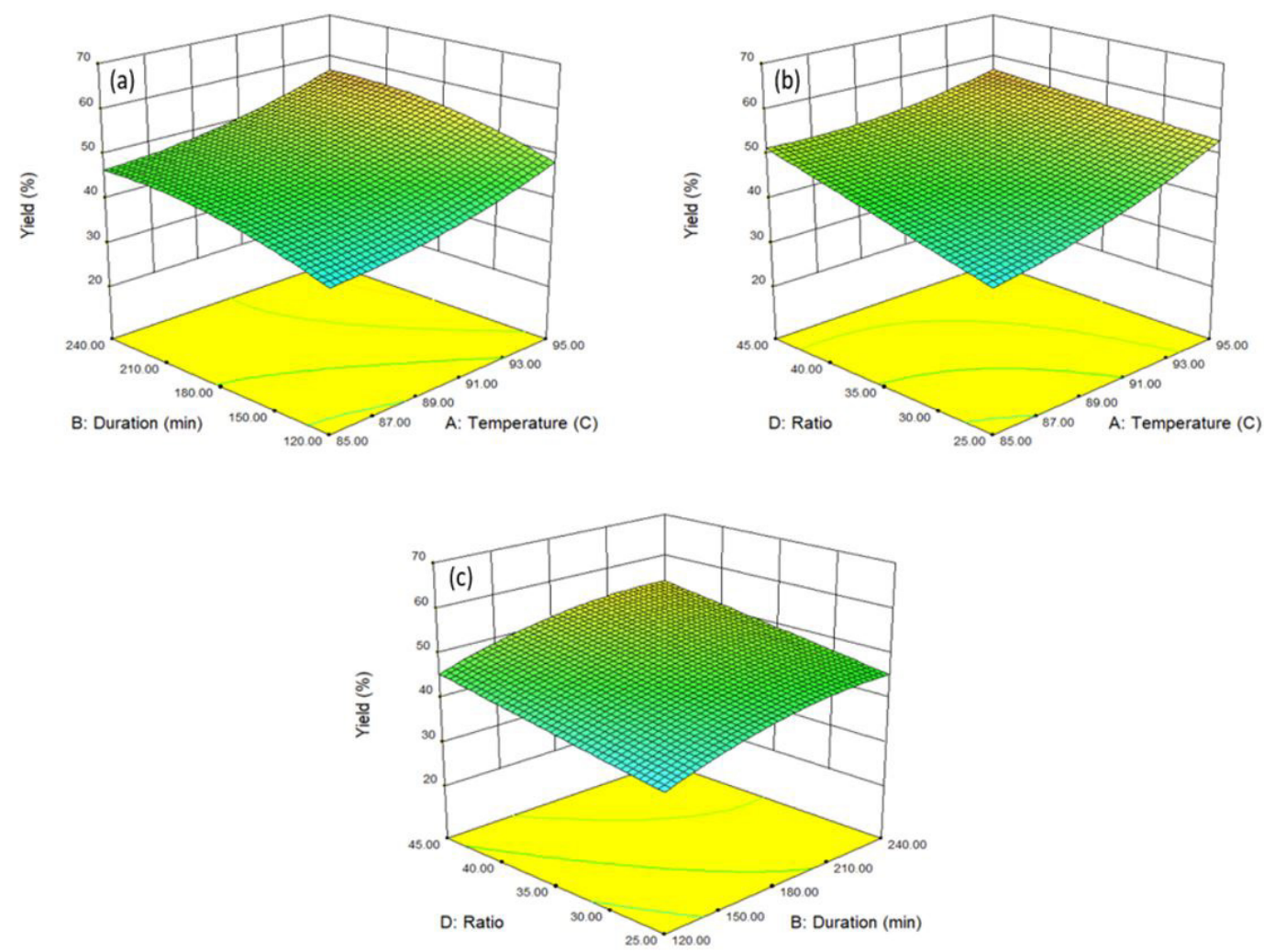

Figure 1. Surface plots for extraction yields at various extraction conditions. (a) $\mathrm{KOH}$ concentration $=0.6 \mathrm{M}$ and solution to seaweed ratio $=35: 1$; (b) $\mathrm{KOH}$ concentration $=0.6 \mathrm{M}$ and extraction duration $=180$ minutes; (c) extraction temperature $=90^{\circ} \mathrm{C}$ and $\mathrm{KOH}$ concentration $=0.6 \mathrm{M}$.

duration were at the central points of $0.6 \mathrm{M}$ and 180 minutes respectively. The response surface curve shown in Figure 1c was generated at extraction temperature of $90{ }^{\circ} \mathrm{C}$ and $\mathrm{KOH}$ concentration and of $0.6 \mathrm{M}$.

It can be seen from Figure 1 that the highest yield was obtained at the highest values of the experimental variables within the experimental domain. The results obtained from yield optimization gave the optimum yield of $60.58 \%$ at $95{ }^{\circ} \mathrm{C}$ extraction temperature, 230.6 minutes of extraction duration, and 45:1 solution to seaweed ratio. At this condition, the predicted gel strength and viscosity were $57.03 \mathrm{~g} / \mathrm{cm}^{2}$ and $273.1 \mathrm{mPa} . \mathrm{s}$ respectively. $\mathrm{KOH}$ concentration did not affect optimization result for extraction yield.

\subsection{Gel strength}

The gel strength of the carrageenan obtained ranged from 42.53 to $70.40 \mathrm{~g} / \mathrm{cm}^{2}$ with an average of $53.50 \mathrm{~g} / \mathrm{cm}^{2}$. The average value of gel strength obtained in this study was almost the same as the gel strength reported previously by Santos (1989) and slightly higher than the results reported by Freile-Pelegrin et al. (2006) and Freile-Pelegrin \& Robledo (2007). The gel strengths obtained in this study were significantly lower than those reported by several researchers (Istini et al., 1994; Vairappan et al., 2003; Wakibia et al., 2006) for carrageenan extracted from Eucheuma spinosum. However, direct comparison with the results reported by these researchers cannot be made since the gels that they used were prepared either by using higher carrageenan concentration (3\%) in the study by Vairappan et al. (2003) or by adding $0.2 \%$ $\mathrm{KCl}$ to enhance gel strength in the study by Istini et al. (1994) and Wakibia et al. (2006).

The gel strength of carrageenan extracted from Eucheuma spinosum in this study can be predicted using a quadratic model. Regression results (not shown) indicate that the quadratic model gives $p$-values of 0.1814 for model and 0.1533 for the lack of fit. The $p$-value for the model indicates that not all of the factors in the model is significant while the p-value for the lack of fit indicates that the quadratic model can adequately predict the gel strength since lack of fit is insignificant ( $p>0.05)$. The results of analysis of variant for the quadratic model (Table 3 ) gave an $F$-value of 4.15 and a $p$-value of 0.0070 . This result suggests the variation in the gel strength can be adequately attributed to the experimental factors in the model.

The results of analysis of variant indicate that the significant factors affecting gel strength $(p<0.05)$ was the quadratic factor of $\mathrm{KOH}$ concentration and the interaction between extraction temperature and ratio of $\mathrm{KOH}$ solution to seaweed. The regression model for gel strength (GS) is given in Equation 3 for coded factors and Equation 4 for actual factors.

$G S=65.29+1.81 X_{1}-2.21 X_{3}-0.41 X_{4}+4.59 X_{1} X_{4}+3.17 X_{3}^{2}$ 
In the above equations, $X_{1}, X_{3}$, and $X_{4}$ represent the coded values for extraction temperature, $\mathrm{KOH}$ concentration, and ratio of $\mathrm{KOH}$ solution to seaweed (v/w) while $T, C$, and $R$ represent the real values of the aforementioned factors.

The regression model in Equation 3 indicates that the most important factor affecting gel strength was the interaction between extraction temperature and ratio of $\mathrm{KOH}$ solution volume to seaweed weight and followed by $\mathrm{KOH}$ concentration. The corresponding response surface plots for gel strength based on Equation 4 are given in Figure 2.

The surface plot in Figure 2a indicate that gel strengths were low when extraction temperature was low and $\mathrm{KOH}$ to seaweed ratio was high. The surface plot also shows that gel strength tended to increase as extraction temperature increases at high $\mathrm{KOH}$ to seaweed ratio (45:1), but tended to decrease at low ratio $(25: 1)$. The plot also shows that as the ratio increases, gel strength tended to increase at high extraction temperature $\left(95^{\circ} \mathrm{C}\right)$ but tended to decrease at lower extraction temperature $\left(85^{\circ} \mathrm{C}\right)$.

The surface plot shown in Figure $2 b$ indicate that gel strength tended to increase as extraction temperature was increased and this trend was consistent at all levels of $\mathrm{KOH}$ concentration.
The plot also shows that gel strength tended to decrease as $\mathrm{KOH}$ concentration was increased from 0.4 to $0.6 \mathrm{M}$ and then increased slightly as $\mathrm{KOH}$ concentration was further increased to $0.8 \mathrm{M}$. The same trend was also shown in Figure $2 \mathrm{c}$. This trend might follow the trend reported by Tuvikene et al. (2006) for carrageenan extracted from Furcellaria lumbricalis and Coccotylus truncatus which indicated that the highest gel strength was obtained from extraction at low $\mathrm{KOH}$ concentration $(0.05 \mathrm{M})$ and the effect of $\mathrm{KOH}$ was insignificant at higher concentration. Optimization for gel strength using Design Expert software gave optimum extraction condition at $95^{\circ} \mathrm{C}$ of extraction temperature, 240 minutes of extraction duration, $0.4 \mathrm{M}$ of $\mathrm{KOH}$ concentration, and $45: 1$ of $\mathrm{KOH}$ to seaweed ratio. At this condition, gel strength was predicted at $60.58 \mathrm{~g} / \mathrm{cm}^{2}$, extraction yield at $59.5 \%$, and carrageenan viscosity at $285.6 \mathrm{mPa}$.s.

\subsection{Viscosity}

The viscosity of carrageenan obtained from the experiments was measured at standard conditions $\left(1.5 \%\right.$ solution at $\left.75^{\circ} \mathrm{C}\right)$ using Brookfield Viscometer (spindle no. 2 at $60 \mathrm{rpm}$ ). The viscosities obtained from the measurements ranged from 259 to $290 \mathrm{mPa}$.s with an average value of $272.55 \mathrm{mPa}$.s. These values were slightly higher that the viscosity of $250-254 \mathrm{mPa}$.s reported by Vairappan et al. (2003) and much higher than the
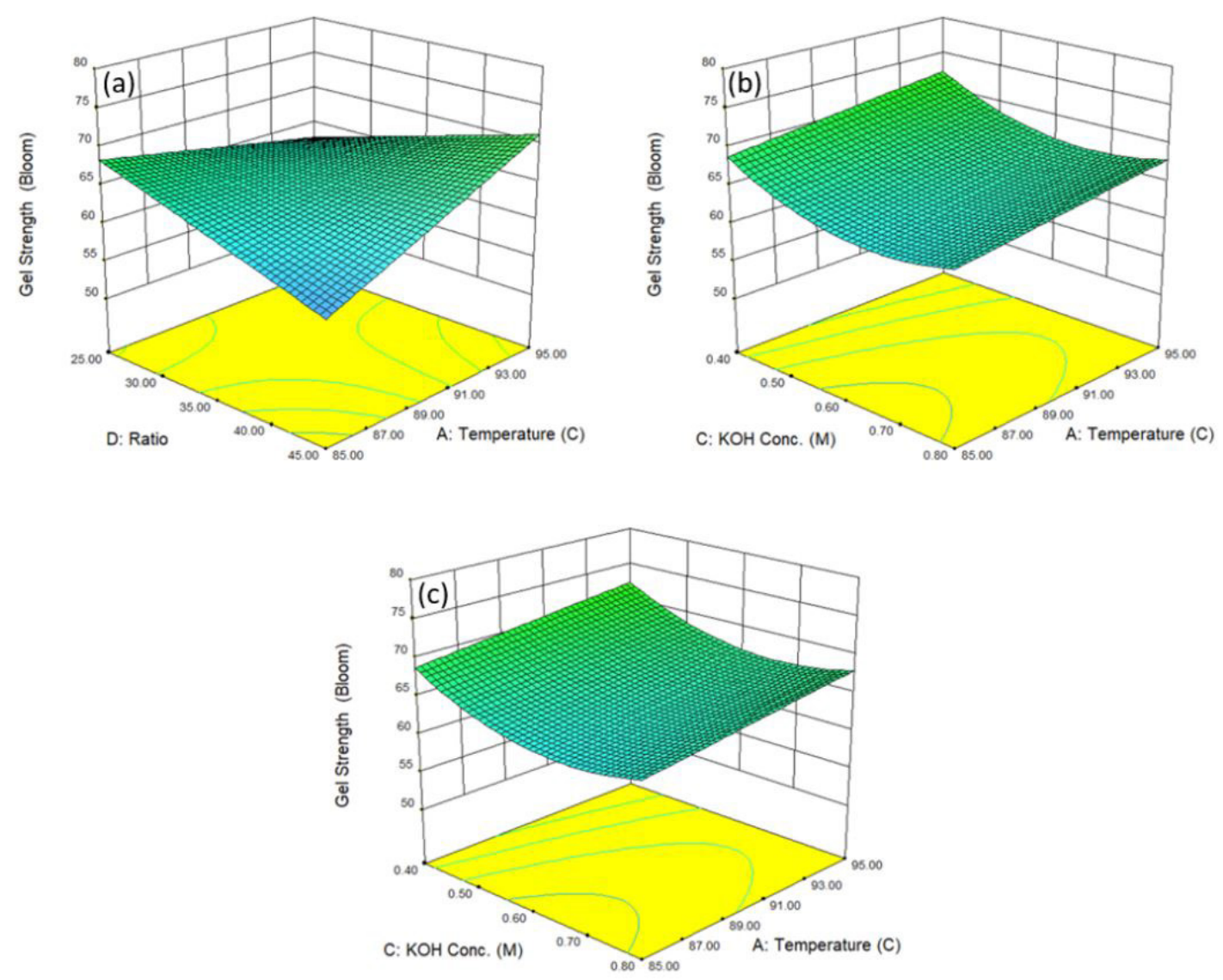

Figure 2. Surface plots of carrageenan gel strength at various extraction conditions. (a) $\mathrm{KOH}$ concentration $=0.6 \mathrm{M}$ and extraction duration $=180 \mathrm{~min}$.; (b) extraction duration $=180 \mathrm{~min}$. and ratio $=35: 1 ;(\mathrm{c})$ temperature $=90^{\circ} \mathrm{C}$ and duration $=180 \mathrm{~min}$. 
values reported for iota carrageenan extracted from Eucheuma denticulatum (Wakibia et al., 2006) and Eucheuma isiforme (Freile-Pelegrin et al., 2006; Freile-Pelegrin \& Robledo, 2007).

Result of sequential regression analysis (not shown) indicates that the recommended model for the viscosity of carrageenan obtained from the extraction experiments was a quadratic model. Analysis of variant for response surface reduced quadratic model for viscosity (Table 3 ) indicated that the model was significant $(\mathrm{p}=0.0002)$ and the effects of extraction temperature, $\mathrm{KOH}$ concentration, and ratio of $\mathrm{KOH}$ volume to seaweed weight were significant while the effect of extraction duration on viscosity was not significant.

It is important to note that the most important factor affecting viscosity was $\mathrm{KOH}$ concentration. The main effect of extraction temperature and ratio of $\mathrm{KOH}$ volume to seaweed weight were not significant $(\mathrm{p}>0.05)$ but their interactions with other experimental factors were significant $(\mathrm{p}<0.05)$. The results of the lack of fit test also indicates that the lack of fit was not significant $(p>0.05)$ which suggested that the model can be used to adequately predict the carrageenan viscosity. The equations obtained from the regression analysis are presented in Equation 5 (for coded factors) and Equation 6 (for actual factors) and the response surface curve for viscosity is shown in Figure 3.

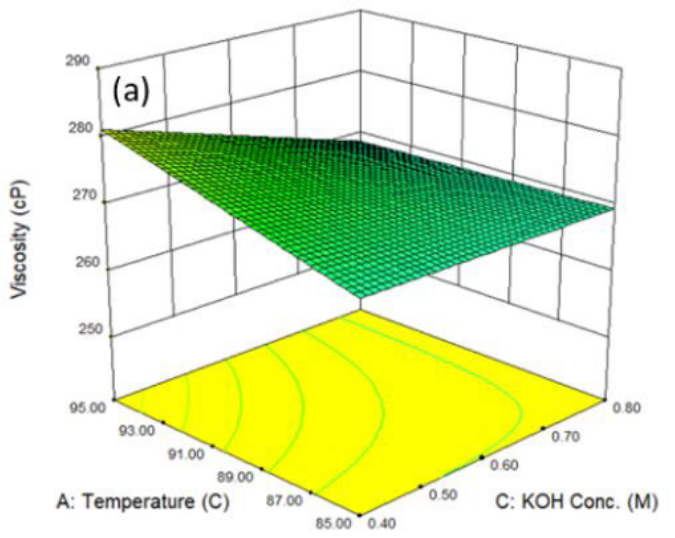

$$
\begin{aligned}
& V=272.48+2.58 X_{1}-3.25 X_{3}-0.5 X_{4}-3.0 X_{1} X_{3}+4.75 X_{1} X_{4} \\
& V=374.7339-1.0083 T+253.75 C-8.6 R-3.0 T C+0.095 T R
\end{aligned}
$$

The variables $X_{1}, X_{3}$, and $X_{4}$ in Equation 5 and $T, C$, and $R$ in Equation 6 represent the coded and the actual factors for extraction temperature, $\mathrm{KOH}$ concentration, and the ratio of solution volume to seaweed weight respectively.

The response surface plots shown in Figure 3 indicate that the viscosity of carrageenan obtained from the extraction process was affected by extraction temperature, $\mathrm{KOH}$ concentration, and solution to seaweed ratio. The effects of interaction between extraction temperature and $\mathrm{KOH}$ concentration and between temperature and solution to seaweed ratio are also evident. Therefore, the response surface plots for the effects of experimental variables on the viscosity of carrageenan can be represented by three curves which show the effect of interaction among the experimental variables. The extraction duration factor was not used in constructing the response surface plots since its effect on viscosity was insignificant.

The viscosity of the carrageenan obtained in this study was generally higher at low $\mathrm{KOH}$ concentration except when it was combined with low extraction temperature. The surface plot on Figure 3 a shows that carrageenan viscosities from extractions

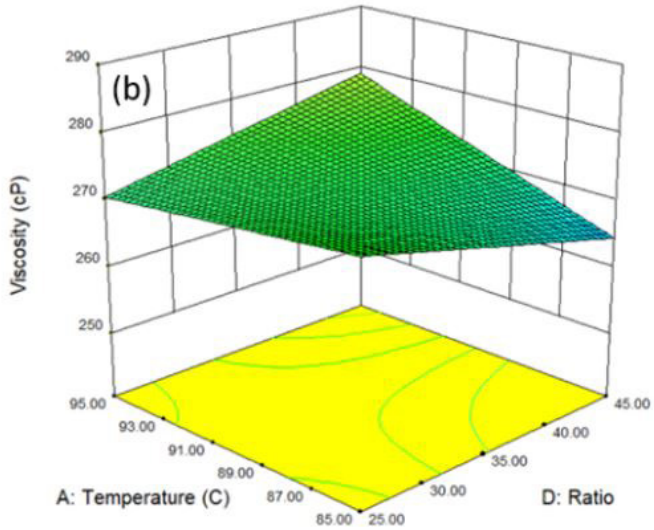

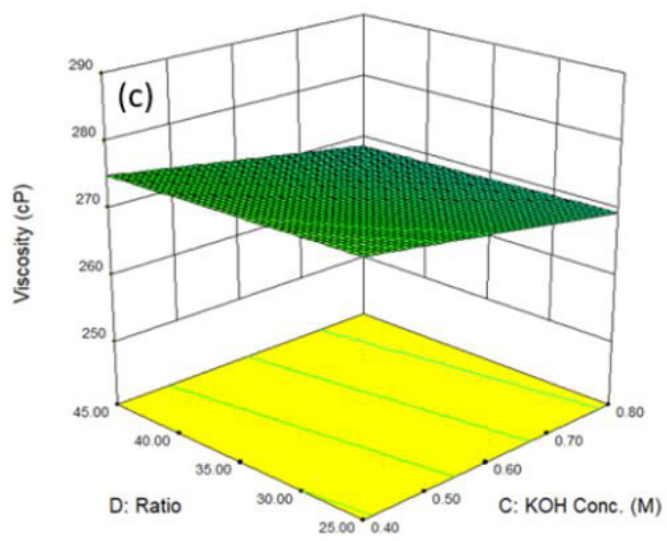

Figure 3. Surface plots of carrageenan viscosity at various extraction conditions. (a) $\mathrm{KOH}$ concentration $=0.6 \mathrm{M}$ and ratio $=35: 1$; $(\mathrm{b})$ extraction duration $=180 \mathrm{~min}$. and concentration $=0.6 \mathrm{M}$; (c) temperature $=90^{\circ} \mathrm{C}$ and duration $180 \mathrm{~min}$. 
at $0.4 \mathrm{M} \mathrm{KOH}$ concentration ranged from $269-282 \mathrm{mPa}$.s while those at $0.8 \mathrm{M}$ ranged from 265-272 mPa.s. Similar trend was found from the surface plot on Figure $3 \mathrm{c}$ which shows higher viscosities from carrageenan extracted at lower $\mathrm{KOH}$ concentration. It can also be seen from Figure $3 a$ and $3 b$ that extraction at lower temperature $\left(85^{\circ} \mathrm{C}\right)$ generally produced carrageenan with lower viscosities (262-273 mPa.s) while extraction at higher temperature $\left(95^{\circ} \mathrm{C}\right)$ produced carrageenan with relatively higher viscosities (267-282 $\mathrm{mPa}$.s). The effect of $\mathrm{KOH}$ to seaweed ratio on viscosity seems to be marginal since the range of viscosity obtained from experiments at lower ratio (267-276 mPa.s) was only slightly different from the range obtained from experiments at higher ratio (262-273 mPa.s). This is also shown from the result of analysis of variance which indicate the insignificance effect of the $\mathrm{KOH}$ to seaweed ratio.

The response surface plot on Figure 3a shows that highest viscosity ( $282 \mathrm{mPa} . \mathrm{s})$ was obtained at $95^{\circ} \mathrm{C}$ extraction temperature, $0.4 \mathrm{M} \mathrm{KOH}$ concentration, 180 minutes of extraction duration, and 35:1 solution to seaweed ratio. The surface plot on Figure 3b indicated that the highest viscosity of $274 \mathrm{mPa}$.s can be obtained at $95^{\circ} \mathrm{C}$ extraction temperature, $45: 1$ solution to seaweed ratio, $0.6 \mathrm{M} \mathrm{KOH}$ concentration (center point), and 180 minutes of extraction duration (center point). For the interaction between $\mathrm{KOH}$ concentration and the ratio (Figure $3 \mathrm{c}$ ), the highest viscosity of around $277 \mathrm{mPa}$.s was obtained at $\mathrm{KOH}$ concentration of $0.4 \mathrm{M}$, ratio of $25: 1$, extraction temperature of $90{ }^{\circ} \mathrm{C}$, and extraction duration of 180 minutes. Results of optimization on viscosity, indicate that optimum viscosity of $285.6 \mathrm{mPa}$.s can be achieved at $95^{\circ} \mathrm{C}$ extraction temperature, 240 minute of extraction duration, $0.4 \mathrm{M}$ of $\mathrm{KOH}$ concentration, and 45:1 of solution to seaweed ratio. At this condition, carrageenan yield and gel strength were predicted at $59.5 \%$ and $60.57 \mathrm{~g} / \mathrm{cm}^{2}$ respectively.

\subsection{Multiple-response optimization}

The single-response optimizations in the previous sections indicate that extraction condition for maximum gel strength and viscosity was identical and only differs from the optimal condition for maximum yield in the extraction duration aspect. Therefore, the optimum extraction condition for multi-response optimization (optimum extraction yield, carrageenan gel strength, and carrageenan viscosity) will not differ significantly from the optimum conditions obtained from the single-response optimization. Results from the multi-response optimization indicate that optimum yield of $59.5 \%$, gel strength of $60.57 \mathrm{~g} / \mathrm{cm}^{2}$, and viscosity of $285,6 \mathrm{mPa}$.s could be obtained at $95^{\circ} \mathrm{C}$ extraction temperature, 230.5 minutes of extraction duration, $0.4 \mathrm{M}$ of $\mathrm{KOH}$ concentration, and 45:1 of solution to seaweed ratio. Three replicates of experimental verification at this optimum condition gave extraction yield $59.77 \pm 2.27 \%$; gel strength $60.03 \pm 1.64 \mathrm{~g} / \mathrm{cm}^{2}$; and viscosity $284.67 \pm 2.52 \mathrm{mPa}$.s.

\section{Conclusions}

Extraction of carrageenan from Eucheuma spinosum can be done effectively using ohmic heating technology. The yields of carrageenan obtained from extraction experiments were comparable to the yields reported by other researchers in literatures. Extraction yield can be predicted adequately using a quadratic model and the significant factors affecting extraction yield were extraction temperature, extraction duration, and solution to seaweed ratio. Carrageenan gel strength and viscosity were significantly affected by extraction temperature, $\mathrm{KOH}$ concentration, and solution to seaweed ratio. Gel strength was a linear function of temperature and ratio and a quadratic function of $\mathrm{KOH}$ concentration while viscosity was a linear function of the three factors. Optimum condition for extraction of carrageenan from Eucheuma spinosum using ohmic heating technology was obtained at $95^{\circ} \mathrm{C}$ extraction temperature, 230.5 minutes of extraction duration, $0.4 \mathrm{M}$ of $\mathrm{KOH}$ concentration, and 45:1 of solution to seaweed ratio. The overall results indicate that the passage of electric current through the solution and the seaweeds during extraction using ohmic heating technology did not negatively affect the quality (gel strength and viscosity) of the carrageenan extracted from Eucheuma denticulatum seaweed. Therefore, application of ohmic heating technology for carrageenan extraction can become a viable alternative since extraction yields and carrageenan quality obtained were comparable to those produced using the energy-inefficient and technically complicated conventional technologies currently used in industries.

\section{Acknowledgements}

This research was partially funded by Indonesian Ministry of Research, Technology, and Higher Education under WCU Program Managed by Institut Teknologi Bandung. Salary and research support is provided by Hasanuddin University.

\section{References}

Abedelmaksoud, T. G., Mohsen, S. M., Duedahl-Olesen, L., Elnikeety, M. M., \& Feyissa, A. H. (2018). Optimization of ohmic heating parameters for polyphenoloxidase inactivation in not-from-concentrate elstar apple juice using RSM. Journal of Food Science and Technology, 55(7), 2420-2428. http://dx.doi.org/10.1007/s13197-018-3159-1. PMid:30042557.

Achir, N., Dhuique-Mayer, C., Hadjal, T., Madani, K., Pain, J.-P., \& Dornier, M. (2016). Pasteurization of citrus juices with ohmic heating to preserve the carotenoid profile. Innovative Food Science \& Emerging Technologies, 33, 397-404. http://dx.doi.org/10.1016/j. ifset.2015.11.002.

Alwis, A. A. P., \& Fryer, P. J. (1990). The use of direct resistance heating in the food industry. Journal of Food Engineering, 11(1), 3-27. http:// dx.doi.org/10.1016/0260-8774(90)90036-8.

Anisuzzama, S. M., Bono, A., Krishnaiah, D., Hussin, N. A., \& Wong, H. Y. (2014). Effects of extraction process conditions on semi refined carrageenan produced by using spray dryer. Journal of Applied Sciences, 14(12), 1283-1288. http://dx.doi.org/10.3923/jas.2014.1283.1288.

Bansal, B., \& Chen, X. D. (2006). Effect of temperature and power frequency on milk fouling in an ohmic heater. Food and Bioproducts Processing, 84(C4), 286-291. http://dx.doi.org/10.1205/fbp.06029.

Bono, A., Anisuzzaman, S. M., \& Ding, O. W. (2014). Effect of process conditions on the gel viscosity and gel strength of semi-refined carrageenan (SRC) produced from seaweed (Kappaphycus alvarezii). Journal of King Saud University -. Engineering and Science, 26(1), 3-9.

Bozkurt, H., \& Icier, F. (2010). Electrical conductivity changes of minced beef-fat blends during ohmic cooking. Journal of Food Engineering, 96(1), 86-92. http://dx.doi.org/10.1016/j.jfoodeng.2009.06.048. 
Buriyo, A. S., Semesi, A. K., \& Mtolera, M. S. P. (2001). The effect of seasons on yield and quality of carrageenan from Tanzanian red alga Eucheuma denticulatum (Gigartinales, Rhodophyta). South African Journal of Botany, 67(3), 488-491. http://dx.doi.org/10.1016/ S0254-6299(15)31168-6.

Castro, I., Teixeira, J. A., Salengke, S., Sastry, S. K., \& Vicente, A. A. (2003). The influence of field strength, sugar and solid content on electrical conductivity of strawberry products. Journal of Food Process Engineering, 26(1), 17-29. http://dx.doi.org/10.1111/j.1745-4530.2003. tb00587.x.

Castro, I., Teixeira, J. A., Salengke, S., Sastry, S. K., \& Vicente, A. A. (2004). Ohmic heating of strawberry products: electrical conductivity measurement and ascorbic acid degradation kinetics. Innovative Food Science \& Emerging Technologies, 5(1), 27-36. http://dx.doi. org/10.1016/j.ifset.2003.11.001.

Chandramishra, P., Jayasankar, R., \& Seema, C. (2006). Yield and quality of carrageenan from Kappaphycus alvarezii subjected to different physical and chemical treatments. Seaweed Research and Utilization, 28(1), 113-117.

Ciancia, M., Noseda, M. D., Matulewicz, M. C., \& Cerezo, A. S. (1993). Alkali-modification of carrageenans: mechanisms and kinetics in the kappa/iota-, mu/nu- and lambda-series. Carbohydrate Polymers, 20(2), 95-98. http://dx.doi.org/10.1016/0144-8617(93)90083-G.

Darvishi, H., Khoshtaghaza, M. H., Zarein, M., \& Azadbakht, M. (2012). Ohmic processing of liquid whole egg, white egg and yolk. Agricultural Engineering International: CIGR Journal, 14(4), 224-230.

Darvishi, H., Khostaghaza, M. H., \& Najafi, G. (2013). Ohmic heating of pomegranate juice: electrical conductivity and $\mathrm{pH}$ change. Journal of the Saudi Society of Agricultural Sciences, 12(2), 101-108. http:// dx.doi.org/10.1016/j.jssas.2012.08.003.

Dawes, C. J. (1977). Seasonal and reproductive aspects of plant chemistry and l-carrageenan from Floridian Eucheuma (Rhodophyta, Gigartinales). Botanica Marina, 20(3), 137-147. http://dx.doi. org/10.1515/botm.1977.20.3.137.

Fattahi, S., \& Zamindar, N. (2020). Effect of immersion ohmic heating on thawing rate and properties of frozen tuna fish. Food Science \& Technology International, 26(5), 453. http://dx.doi. org/10.1177/1082013219895884. PMid:32013563.

Fostier, A. H., Kornprobst, J. M., \& Combaut, G. (1992). Chemical composition and rheological properties of carrageenans from two Senegalese Solieriaceae Anatheca montagnei Schmitz and Meristotheca senegalensis Feldmann. Botanica Marina, 35(4), 351-355. http:// dx.doi.org/10.1515/botm.1992.35.4.351.

Freile-Pelegrin, Y., \& Robledo, D. (2007). Carrageenan of Eucheuma isiforme (Solieriaceae, Rhodophyta) from Nicaragua. Journal of Applied Phycology, 20(5), 537-541. http://dx.doi.org/10.1007/ s10811-007-9270-8.

Freile-Pelegrin, Y., Robledo, D., \& Azamar, J. A. (2006). Carrageenan of Eucheuma isiforme (Solieriaceae, Rhodophyta) from Yucatan, Mexico. I. Effect of extraction conditions. Botanica Marina, 49(1), 65-71. http://dx.doi.org/10.1515/BOT.2006.008.

Getchel, B. E. (1935). Electric pasteurization of milk. Agricultural Engineering, 16(10), 408-410.

Halleux, D., Piette, G., Buteau, M.-L., \& Dostie, M. (2005). Ohmic cooking of processed meats: Energy evaluation and food safety considerations. Canadian Biosystems Engineering, 47(3), 41-47.

Hasizah, A., Mahendradatta, M., Laga, A., Metusalach, M., Supratomo, S., Waris, A., \& Salengke, S. (2018). A novel ohmic-based technology for seaweed processing. International Food Research Journal, 25(4), 1341-1348.
Icier, F., \& Bozkurt, H. (2011). Ohmic heating of liquid whole egg: rheological behaviour and fluid dynamics. Food and Bioprocess Technology, 4(7), 1253-1263. http://dx.doi.org/10.1007/s11947009-0229-4.

Icier, F., \& Ilicali, C. (2005). Temperature dependent electrical conductivities of fruit pures during ohmic heating. Food Research International, 38(10), 1135-1142. http://dx.doi.org/10.1016/j.foodres.2005.04.003.

Istini, S., Ohno, M., \& Kusunose, H. (1994). Methods of analysis for agar, carrageenan, and alginate in seaweed. Bulletin of Marine Science and Fishery. Kochi Univ., 14, 49-55.

Kasler, D. R., \& Sastry, S. K. (2019). Effects of frequency on the electrical conductivity of whole shell egg components. Journal of Food Process Engineering, 42(4), e13056. http://dx.doi.org/10.1111/jfpe.13056.

Kulshrestha, S., \& Sastry, S. K. (2003). Frequency and voltage effects on enhanced diffusion during moderate electric field (MEF) treatment. Innovative Food Science \& Emerging Technologies, 4(2), 189-194. http://dx.doi.org/10.1016/S1466-8564(03)00003-1.

Kuriya, S. P., Silva, R., Rocha, R. S., Guimarães, J. T., Balthazar, C. F., Pires, R. P. S., Tavares, E. R. T. Fo., Pimentel, T. C., Freitas, M. Q., Cappato, L. P., Raices, R. S. L., Cruz, A. G., Silva, M. C., \& Esmerino, E. A. (2020). Impact assessment of different electric fields on the quality parameters of blueberry flavored dairy desserts processed by Ohmic Heating. Food Research International, 134, 109235. http:// dx.doi.org/10.1016/j.foodres.2020.109235. PMid:32517929.

Lebovka, N. I., Praproscic, I., Ghnimi, S., \& Vorobiev, E. (2005). Does electroporation occur during the ohmic heating of food? Journal of Food Science E. Food Engineering and Physical Properties, 70(5), 305-311.

Lima, M., \& Sastry, S. K. (1999). The effects of ohmic heating frequency on hot-air drying rate and juice yield. Journal of Food Engineering, 41(2), 115-119. http://dx.doi.org/10.1016/S0260-8774(99)00080-1.

Mercali, G. D., Jaeschke, D. P., Tessaro, I. C., \& Marczak, L. D. F. (2013). Degradation kinetics on anthocyanins in acerola pulp: comparison between ohmic and conventional heat treatment. Food Chemistry, 136(2), 853-857. http://dx.doi.org/10.1016/j.foodchem.2012.08.024. PMid:23122136.

Mizrahi, S. (1996). Leaching of soluble solids during blanching of vegetables by ohmic heating. Journal of Food Engineering, 29(2), 153-166. http://dx.doi.org/10.1016/0260-8774(95)00074-7.

Moses, B. D. (1938). Electric pasteurization of milk. Agricultural Engineering, 19, 525-526.

Pires, R. P. S., Cappato, L. P., Guimaraes, J. T., Rocha, R. S., Silva, R., Balthazar, C. F., Freitas, M. Q., Silva, P. H. F., Cucinelli, R. P. No., Tavares, M. I. B., Granato, D., Raices, R. S. L., Silva, M. C., \& Cruz, A. G. (2020). Ohmic heating for infant formula processing: Evaluating the effect of different voltage gradient. Journal of Food Engineering, 280, 109989. http://dx.doi.org/10.1016/j.jfoodeng.2020.109989.

Rocha, R. S., Silva, R., Guimarães, J. T., Balthazar, C. F., Pimentel, T. C., Cucinelli, R. P. No., Tavares, M. I. B., Esmerino, E. A., Freitas, M. Q., Cappato, L. P., Calvacanti, R. N., Rodrigues, F. N., Raices, R. S. L., Silva, M. C., \& Cruz, A. G. (2020a). Possibilities for using ohmic heating in Minas Frescal cheese production. Food Research International, 131, 109027. http://dx.doi.org/10.1016/j. foodres.2020.109027. PMid:32247497.

Rocha, R. S., Silva, R., Guimarães, J. T., Balthazar, C. F., Silveira, M. R., Martins, A. A., Rojas, V. P., Graça, J. S., Pimentel, T. C., Esmerino, E. A., Sant'Ana, A. S., Granato, D., Freitas, M. Q., Barros, M. E., Silva, M. C., \& Cruz, A. G. (2020b). Ohmic heating does not influence the biochemical properties of Minas Frescal cheese but decreases uric acid levels in healthy Wistar rats. Journal of Dairy Science, 103(6), 4929-4934. http://dx.doi.org/10.3168/jds.2019-17712. PMid:32229115. 
Salengke, S., \& Sastry, S. K. (2005). Effect of ohmic pretreatment on the drying rate of grapes and adsorption isotherm of raisins. Drying Technology, 23(3), 551-564. http://dx.doi.org/10.1081/DRT-200054131.

Salengke, S., \& Sastry, S. K. (2007a). Effects of ohmic pretreatment on oil uptake of potato slices during frying and subsequent cooling. Journal of Food Process Engineering, 30(1), 1-12. http://dx.doi. org/10.1111/j.1745-4530.2007.00096.x.

Salengke, S., \& Sastry, S. K. (2007b). Experimental investigation of ohmic heating of solid-liquid mixtures under worst-case heating scenarios. Journal of Food Engineering, 83(3), 324-336. http://dx.doi. org/10.1016/j.jfoodeng.2007.02.060.

Salengke, S., \& Sastry, S. K. (2007c). Models for ohmic heating of solid-liquid mixtures under worst-case heating scenarios. Journal of Food Engineering, 83(3), 337-355. http://dx.doi.org/10.1016/j. jfoodeng.2007.03.026.

Santos, G. A. (1989). Carrageenans of species of Eucheuma J. Agardh and Kappaphycus Doty (Solieriaceae, Rhodophyta). Aquatic Botany, 36(1), 55-67. http://dx.doi.org/10.1016/0304-3770(89)90091-0.

Sarang, S., Sastry, S. K., \& Knipe, L. (2008). Electrical conductivity of fruits and meats during ohmic heating. Journal of Food Engineering, 87(3), 351-356. http://dx.doi.org/10.1016/j.jfoodeng.2007.12.012.

Sastry, S. K., \& Palaniappan, S. (1991). Electrical conductivity of selected juices: influences of temperature, solids content, applied voltage, and particle size. Journal of Food Process Engineering, 14(4), 247-260. http://dx.doi.org/10.1111/j.1745-4530.1991.tb00135.x.

Schreier, P., Reid, D., \& Fryer, P. (1993). Enhanced diffusion during the electrical heating of foods. International Journal of Food Science \& Technology, 28(3), 249-260. http://dx.doi.org/10.1111/j.1365-2621.1993. tb01270.x.

Shirsat, N., Lyng, J. G., Brunton, N. P., \& McKenna, B. M. (2004). Conductivities and ohmic heating of meat emulsion batters. Journal of
Muscle Foods, 15(2), 121-137. http://dx.doi.org/10.1111/j.1745-4573.2004. tb00716.x.

Tuvikene, R., Truus, K., Vaher, M., Kailas, T., Martin, G., \& Kersen, P. (2006). Extraction and quantification of hybrid carrageenans from the biomass of the red algae Furcellaria lumbricalis and Coccotylus truncatus. Proceedings of the Estonian Academy of Sciences. Chemistry, 55(1), 40-53.

Uy, S. F., Easteal, A. J., Farid, M. M., Keam, R. B., \& Conner, G. T. (2005). Seaweed processing using industrial single-mode cavity microwave heating: a preliminary investigation. Carbohydrate Research, 340(7), 1357-1364. http://dx.doi.org/10.1016/j.carres.2005.02.008. PMid:15854606.

Vairappan, C. S., Han, T. K., \& Razalie, R. (2003). Seasonal fluctuations in carrageenan yield in Eucheuma spinosum cultural in coastal areas of Pulau Balambangan, Kudat, Sabah. Borneo Science, 14(1), 55-61.

Wakibia, J. G., Bolton, J. J., Keats, D. W., \& Raitt, L. M. (2006). Seasonal changes in carrageenan yield and gel properties in three commercial eucheumoids grown in southern Kenya. Botanica Marina, 49(3), 208-215. http://dx.doi.org/10.1515/BOT.2006.026.

Wang, W.-C., \& Sastry, S. K. (2002). Effects of moderate electrothermal treatments on juice yield from cellular tissue. Innovative Food Science \& Emerging Technologies, 3(4), 371-377. http://dx.doi.org/10.1016/ S1466-8564(02)00054-1.

Webber, V., Carvalho, S. M., Ogliari, P. J., Hayashi, L., \& Barreto, P. L. M. (2012). Optimization of the extraction of carrageenan from Kappaphycus alvarezii using response surface methodology. Food Science and Technology, 32(4), 812-818. http://dx.doi.org/10.1590/ S0101-20612012005000111.

Zell, M., Lyng, J. G., Cronin, D. A., \& Morgan, D. J. (2009). Ohmic heating of meats: Electrical conductivities of whole meats and processed meat ingredients. Meat Science, 83(3), 563-570. http:// dx.doi.org/10.1016/j.meatsci.2009.07.005. PMid:20416659. 